\section{Europe: Governance, Expectations, and Reform Peter Maassen}

Peter Maassen is professor of higher education at the University of Oslo; senior researcher at NIFU STEP (the Research Institute for Studies in Innovation, Research, and Education), Oslo, Norway; and director of Hedda (www.uio.no/hedda), a consortium of European centers for higher education research. E-mail: peter.maassen@ped.uio.no.

$E^{u}$ uropean higher education, especially the traditional research university, is currently in a state of institutional flux. In Europe, higher education institutions have historically played an important role in nation building-supplying states with educated manpower, building national consciousness and identity, integrating national elites, and providing a national research capacity for economic and social development. Consequently, higher education institutions have long been regarded as national institutions, with the national authorities responsible for regulations and funding. The Treaty of Maastricht (I992), which forms the legal basis for the European Union (EU), also viewed higher education as national entities, implying that the European Commission could not undertake any initiative itself for harmonizing higher education.

\section{Growing INVOLVEMENT OF THE EU}

Recently, however, the need for a joint European policy perspective on higher education has become more widely accepted. The European commission, in particular, has claimed that a dynamic knowledge-based economy requires modernization of European universities and colleges. The president of the commission (José Manuel Barroso) and the commissioners responsible for higher education and for research state that higher education has never featured so high on the commission's agenda, that the political interest in higher education is growing, and that reforms are urgently needed.

In line with this, the commission has produced a stream of documents promoting radical reforms. A "Charter for Researchers" specifying roles and responsibilities has been developed; the European Research Council is presented as an important institutional innovation and an autonomous entity under scientific leadership. The European Institute of Technology is promoted as Europe's "knowledge flagship," bringing together research, education, and innovation. Its governing board is to consist of academics and businesspeople seen as able to select the best areas for long-term investment in research within a Io-to-I5-year period.

\section{A New University Model?}

This EU focus on higher education is accompanied by an intense mistrust of university traditions, as can be illustrated by the following quote from Commissioner Ján Figel: "We need a new model ... [to] demonstrate to countries where university models still hark back to the days of Humboldt that today there are additional ways of doing things."

The "new model" proposed by the commission emphasizes leadership, management, and entrepreneurship more than individuals' academic freedom, internal democracy, and the organizing role of academic disciplines. Higher education institutions should gain greater autonomy but must also produce more accountability. This transition requires new internal governance structures involving strategic priorities and professional management. Universities and colleges must overcome their fragmentation into faculties, departments, laboratories, research centers, and administrative units and instead target their efforts collectively on institutional priorities for research, teaching, and innovation. This mission should include multilateral consortia, joint-degree arrangements, networks, and collaborations. The commission also supports a further separation of teaching from research and more differentiation and stratification among higher education institutions yet with fewer differences between countries and more within each country.

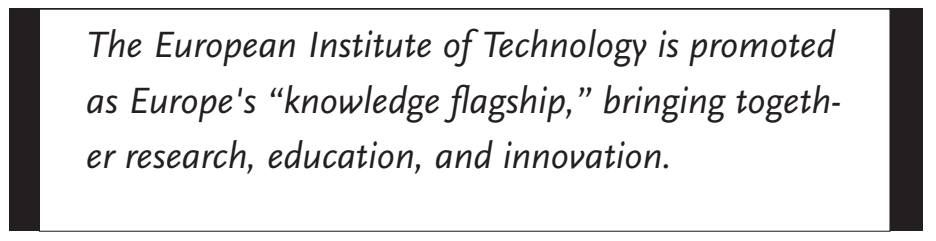

International competitiveness and higher education's contribution to society's economic and social progress are seen to be held back by the role historically played by governments. In the new model the state should serve less predominantly as funder, receiver of graduates, and user of knowledge. There should be governance by standardization, dialogue, benchmarking, and exchange of "good practice." Higher education's mission for society requires an external system of quality assurance and accreditation and a move from state control to being accountable to society and customers. External controls are called for-through increased competition, externally defined standards and goals, demands for results that can be documented in numbers, and external monitoring units.

Reforms are driven both by the fear of falling behind and by promises of new resources. With a funding deficit, investments in European universities need to be increased and diversified. Compared to the United States, on average an EUR I0,000 gap in resources per student exists, according to the European Commission. The commission stated that higher education as the "knowledge industry," like other industries, urgently needs reform and that the goals and remedies are basically the same as for other sectors. As was argued last year 
by European Commission President Barroso, "Europe's economic future depends on having the most highly educated and trained people, with the full range of skills and the adaptability required in a 'knowledge economy.' That is why we must boost investment in higher education significantly. The commission is suggesting a target [investment for higher education] of 2 percent of gross domestic product by $2010 . "$

\section{Public Money for Private Higher Education}

\section{Daniel C. Levy}

Daniel Levy is director of the Program for Research on Private Higher Education (PROPHE) and is a SUNY Distinguished Professor. Address: ED321, University at Albany, Albany, NY 12222, USA. E-mail: dlevy@albany.edu.

IHE devotes a column in each issue to a contribution from PROPHE, the Program for Research on Private Higher Education, headquartered at the University at Albany. See http://www.albany.edu/dept/eaps/prophe/.

$\mathrm{P}$ ublic money for private higher education is a major policy issue for governments, the general public, and of course private institutions-all the more so as the private sector has risen to roughly 30 percent of total global enrollment and is continuing to grow. Yet, a key baseline is the fact that public funding of private higher education is the exception, not the rule. This reality is often obscured by contrary examples that lead to the absurd notion that source of income does not seriously distinguish the two sectors of higher education. In fact, just as public higher education is overwhelmingly sustained by public money, private higher education is just as overwhelmingly sustained by private money. This generalization is particularly strong in the developing world and the postcommunist world-the two greatest sites of private higher education expansion. Nonetheless, examples of public money for private higher education are significant and increasing.

\section{Full-Blown National Cases}

Probably the most-cited cases where private higher education depends on public funding, to almost the same extent as public higher education does, are found in Belgium and the Netherlands. The roots lie early in the last century, with the idea that religious and cultural groups could have their own private universities, and since all groups hold that same right the public would legitimately fund all institutions. This is essentially a voucher principle. Though not as much in governance as in finance, private universities would resemble public ones except for the one area of cultural distinctiveness.

Chile by midcentury came to provide a clear developing country case of public funding of the private sector. Alongside the two public universities, all six private ones (both religious and secular) became basically publicly funded. A startling change then ensued under military neoliberal rule in the I980s: the proliferation of truly private universities. These constitute the "private sector," whereas the six prior institutions are labelled "old privates."

With independence, India saw a massive shift in funding and governance. An enormous network of private colleges, affiliated to universities, became essentially public. Here, too, however, a fresh wave of private proliferation has exploded onto the scene, accounting now for perhaps 30 percent of total enrollments.

Other cases of public takeover were even more extreme but concerned abolition of private higher education, not just public funding of still formally private institutions. In the I970s Turkey was one example and the communist bloc the major set of examples.

\section{RATIONALES}

Justifications for public funding are multiple, as are arguments against that policy. One rational is fair and equal treatment of students, regardless of their institutions. Another is access, particularly if the private sector offers slots beyond what the

Probably the most-cited cases where private higher education depends on public funding, to almost the same extent as public higher education does, are found in Belgium and the Netherlands.

public sector provides yet needs certain cost-sharing. The access rationale strengthens in areas where the populations are less privileged. More broadly, in public-private partnerships the public side pursues public goals, with public money, but entrusts management largely to private nonprofit organizations. Sometimes this policy involves direct contracting out for a specific public end but often just general ongoing grants.

Other major rationales involve quality and incentives. Where this orientation is found the whole private sector does not qualify for funding; instead, public money is dispersed according to sets of criteria. Funding is thus "sector blind," which hardly insures equal amounts to the two sectors. Indeed, most private institutions and units within favored institutions may not receive such money. Public money may motivate private institutions to improve (e.g., seek accreditation) or expand; in turn, governments may relish forcing public universities to compete for some of their funding. Often, private institutions continue to carry out their most basic goals 